\title{
Pengaruh Partisipasi Anggaran, Kejelasan Sasaran Anggaran dan Kohesivitas Kelompok terhadap Senjangan Anggaran
}

\author{
Ni Putu Evitania Precilia ${ }^{1}$ \\ Fakultas Ekonomi dan Bisnis \\ Universitas Udayana, Indonesia
}

\author{
Ni Putu Sri Harta Mimba ${ }^{2}$ \\ Fakultas Ekonomi dan Bisnis \\ Universitas Udayana, Indonesia
}

\begin{abstract}
Surel : evitaniap.ep@gmail.com
ABSTRAK

Tujuan penelitian ini adalah untuk menguji pengaruh partisipasi anggaran, kejelasan sasaran anggaran dan kohesivitas kelompok terhadap senjangan anggaran di Rumah Sakit Daerah Mangusada Kabupaten Badung. Sebanyak 36 orang dipilih menjadi responden. Metode penentuan sampel pada penelitian ini adalah purposive sampling dan teknik analisis data penelitian ini menggunakan analisis regresi linier berganda. Hasil penelitian ini menunjukkan bahwa partisipasi anggaran dan kohesivitas kelompok berpengaruh positif terhadap senjangan anggaran, sedangkan kejelasan sasaran anggaran berpengaruh negatif terhadap senjangan anggaran di Rumah Sakit Daerah Mangusada Kabupaten Badung.
\end{abstract}

Kata Kunci: Partisipasi Anggaran; Kejelasan Sasaran Anggaran; Kohesivitas Kelompok; Senjangan Anggaran.

\section{Effects of Budget Participation, Clarity of Budget Goals and Group Cohesiveness on Budgetary Slack}

\begin{abstract}
The purpose of this study was to examine the effect of budget participation, clarity of budget targets and group cohesiveness on budgetary slack at the Mangusada Regional Hospital in Badung Regency. A total of 36 people were selected as respondents. The sampling method in this study is purposive sampling and the data analysis technique of this study uses multiple linear regression analysis. The results of this study indicate that budgetary participation and group cohesiveness have a positive effect on budgetary slack, while the clarity of budget targets has a negative effect on budgetary slack in the Mangusada Regional Hospital in Badung Regency.

Keywords: Budget Participation; Clarity of Budget Goals; Group Cohesiveness; Budgetary Slack.
\end{abstract}

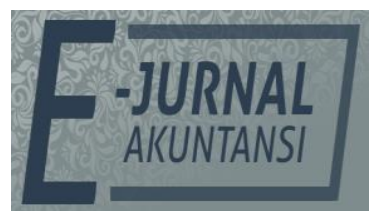

e-ISSN 2302-8556

Vol. 30 No. 9

Denpasar, September 2020 Hal. 2381-2391

DOI:

10.24843/EJA.2020.v30.i09.p16

PENGUTIPAN:

Precilia, N. P. E. \& Mimba, N. P. S. H. (2020). Pengaruh Partisipasi Anggaran, Kejelasan Sasaran Anggaran dan Kohesivitas Kelompok terhadap Senjangan Anggaran. E-Jurnal Akuntansi, 30(9), 2381-2391

RIWAYAT ARTIKEL: Artikel Masuk: 1 Mei 2020 Artikel Diterima: 19 Juli 2020

Artikel dapat diakses : https://ojs.unud.ac.id/index.php/Akuntansi/index 


\section{PENDAHULUAN}

Penyusunan anggaran membutuhkan partisipasi dari anggota dalam organisasi baik atasan maupun pihak manajemen sebagai pengelola perusahaan terlibat dan memiliki pengaruh dalam proses penyusunan dan penentuan target anggaran. Partisipasi dalam proses penyusunan anggaran juga memberikan informasi kepada para pimpinan satuan kerja pusat pertanggungjawaban untuk menetapakan isi anggaran yang akan disusun. Wewenang yang dimiliki ini memberikan peluang bagi partisipan untuk menyalahgunakan kewenangannya dalam mempermudah pencapaian anggaran sehingga dapat merugikan organisasi tersebut (Erina \& Suartana, 2016). Sehingga, dalam partisipasi penyusunan anggaran dapat menimbulkan masalah sehingga terjadi senjangan anggaran. Senjangan anggaran dipengaruhi oleh beberapa faktor diantaranya partisipasi anggaran. Partisipasi anggaran merupakan suatu proses dimana penyusunan anggaran ikut terlibat dan mempunyai pengaruh dalam penentuan anggaran (Arthaswadaya, 2015).

Selain partisipasi anggaran, faktor yang mempengaruhi senjangan anggaran adalah kejelasan sasaran anggaran. Kejelasan sasaran anggaran didefinisikan sejauh mana tujuan anggaran ditetapkan secara jelas dan spesifik dengan tujuan agar dapat dimengerti oleh orang yang bertanggung jawab atas pencapaian sasaran anggaran terbut. Adanya sasaran anggaran yang jelas, maka akan mempermudah dalam mempertanggungjawabkan keberhasilan dan kegagalan dari suatu pelaksanaan tugas yang telah dilaksanakan dalam rangka untuk mencapai tujuan-tujuan dan sasaran-sasaran yang telah ditetapkan sebelumnya (Pitasari et al., 2014). Penelitian yang dilakukan oleh Biantara \& Dwija Putri, (2014) menunjukkan hasil yang berbeda yaitu kejelasan sasaran anggaran mempunyai pengaruh positif pada senjangan anggaran yang berarti semakin jelas sasaran anggaran, kemungkinan terjadinya senjangan anggaran semakin besar. Rahman, (2009) meneliti pengaruh kejelasan sasaran anggaran dan hasilnya menunjukkan tidak terdapat pengaruh antara kejelasan sasaran anggaran terhadap senjangan anggaran yang berarti kejelasan sasaran anggaran tidak mengurangi adanya senjangan anggaran.

Dalam proses penyusunan anggaran juga dibutuhkan kohektivitas kelompok. Kohesivitas kelompok adalah keadaan dimana karyawan satu dengan karyawan lainnya yang tergabung dalam satu kelompok saling memiliki pertalian dan memotivasi satu sama lain untuk tetap menjadi anggota kelompok dan secara bersama-sama mencapai tujuan yang mereka inginkan Lestari \& Wisadha, (2015). Bila kohesivitas tinggi dan kelompok menerima serta sepakat dengan tujuan formal organisasi, maka perilaku kelompok akan positif ditinjau dari sisi organisasi formal (Robbins \& Judge, 2006). Demikian pula dalam partisipasi penyusunan anggaran, jika tujuan kelompok dengan kohesivitas yang tinggi tidak sesuai dengan tujuan manajemen organisasi maka hal tersebut dapat menimbulkan terjadinya kesenjangan anggaran (budgetary slack).

Senjangan anggaran bukan hanya dapat terjadi lingkungan perusahaan, organisasi swasta tetapi juga dapat terjadi pada sektor publik. Anggaran sektor publik merupakan suatu instrumen perencanaan, pengendalian dan akuntabilitas publik yang ditandai adanya penentuan visi, misi, tujuan, sasaran, dan target organisasi publik serta adanya penetapan indikator kinerja sebagai ukuran 
kuantitatif yang menggambarkan tingkat pencapaian suatu tujuan yang telah ditetapkan. Anggaran sektor publik merupakan instrumen akuntabilitas atas pengelolaan dana publik dan pelaksanaan program-program yang dibiayai dengan uang publik (Dianthi \& Wirakusuma, 2017). Penelitian ini dilaksanakan di Rumah Sakit Umum milik Pemerintah Kabupaten Badung. Rumah Sakit Daerah Mangusada Kabupaten Badung merupakan Rumah Sakit Pemerintah dikelola oleh Pemerintah, Pemerintah Daerah dan Badan Hukum yang bersifat nirlaba. Rumah Sakit Daerah Kabupaten Badung Mangusada adalah Badan Layanan Umum Daerah (BLUD). Badan Layanan Umum Daerah adalah instansi di lingkungan Pemerintah yang dibentuk untuk memberikan pelayanan kepada masyarakat berupa penyediaan barang dan/atau jasa yang dijual tanpa mengutamakan mencari keuntungan dan dalam melakukan kegiatannya didasarkan pada prinsip efisiensi dan produktivitas.

Dalam proses penyusunan rencana kegiatan dan anggaran, usulan rencana kegiatan Rumah Sakit Daerah Mangusada Kabupaten Badung ditelaah dan dilengkapi oleh masing-masing bidang yang ada di Rumah Sakit Daerah Mangusada Kabupaten Badung. Usulan rencana kegiatan yang disusun oleh masing-masing Bidang dibuat dalam bentuk Rencana Anggaran dan Biaya (RAB) dan Kerangka Acuan Kerja (KAK) yang akan diserahkan kepada Direktur Rumah Sakit. Sebelum RAB dan KAK yang telah disusun disetorkan kepada Direktur, disetorkan dahulu melalui Sub Bagian Penyusunan Program Keuangan dan Akuntansi. Sub Bagian Penyusunan Program dan Akuntansi akan melakukan kompilasi Usulan Rencana Kegiatan, RAB dan KAK masing-masing Bidang ke dalam Format Rencana Kerja dan Anggaran (RKA) untuk alokasi anggaran APBD dan ke dalam format Rencana Bisnis dan Anggaran (RBA) untuk alokasi anggaran dari pendapatan BLUD. Hasil kompilasi RKA dan RBA dibahas bersama unsur pengelola rumah sakit yang dipimpin oleh Direktur. Hasil pembahasan di review oleh Dewan Pengawas secara langsung dalam rapat pembahasan internal. Jika RKA dan RBA yang sudah dibahas dan direview sudah sesuai, maka dapat disahkan menjadi dokumen Rencana Bisnis dan Anggaran BLUD (RBA-BLUD) oleh Bupati dan juga disahkan untuk penetapan APBD dan pengesahan Dokumen Pelaksanaan Anggaran APBD (DPA-APBD) oleh PPKD. Dalam penelitian ini pejabat struktural diantaranya Direktur, masing-masing Bidang, Bagian, Subbagian, dan Seksi memiliki peranan penting dalam proses penyusunan serta penetapan target anggaran.

Hasil penelitian Rahmiati, (2013), menyebutkan bahwa partisipasi anggaran dapat menurunkan senjangan anggaran karena partisipasi anggaran dipandang dapat sebagai suatu proses dalam organisasi yang melibatkan para manajer dalam penentuan tujuan anggaran yang menjadi tanggung jawab organisasi secara menyeluruh, sehingga partisipasi pihak manajemen sebagai pengelola perusahaan akan meningkatkan kebersamaan, menumbuhkan rasa memiliki, inisiatif untuk menyumbangkan ide dalam perbuatan, ini berarti partisipasi anggaran berpengaruh negatif terhadap senjangan anggaran. Falikhatun, (2007) meneliti pengaruh partisipasi anggaran terhadap budgetary slack pada rumah sakit umum daerah se-Jawa Tengah. Hasil penelitian menunjukkan bahwa partisipasi anggaran berpengaruh positif dan signifikan terhadap budgetary slack. 
Menurut Lau \& Eggleton, (2003) dalam proses partisipasi penganggaran inisiatif yang besar dimiliki bawahan untuk menciptakan kesenjangan anggaran disebabkan karena adanya target anggaran yang diberikan kepada bawahan serta dibandingkan atasan bawahan memiliki informasi lebih. Kebutuhan yang tinggi cenderung akan dinyatakan bawahan dan produktivitas yang rendah dalam anggaran yang disusunnya untuk memudahkan anggaran tersebut tercapai (Widanaputra \& Mimba, 2014).

Hipotesis yang digunakan untuk menguji hubungan antara partisipasi anggaran terhadap senjangan anggaran adalah semakin tinggi partisipasi yang diberikan kepada pihak manajemen sebagai pengelola perusahaan, maka pihak manajemen sebagai pengelola perusahaan berusaha agar anggaran yang mereka susun mudah dicapai serta mengurangi risiko yang mungkin dihadapi apabila tidak mampu mencapai target yang diinginkan dengan cara menciptakan senjangan anggaran agar terjadinya kesesuaian target anggaran dan realisasinya, oleh karena itu rumusan hipotesis sebagai berikut.

$\mathrm{H}_{1}$ : Partisipasi anggaran berpengaruh positif terhadap senjangan anggaran.

Pitasari et al., (2014) meneliti mengenai pengaruh kejelasan sasaran anggaran terhadap senjangan anggaran pada Dinas Pemerintah Kabupaten Klungkung dan mendapatkan hasil bahwa kejelasan sasaran anggaran berpengaruh negatif terhadap senjangan anggaran. Hal ini berarti bahwa semakin tinggi tingkat kejelasan sasaran anggaran maka risiko terjadinya senjangan anggaran akan semakin rendah. Begitu pula sebaliknya, semakin rendah tingkat kejelasan sasaran anggaran, maka akan semakin tinggi kemungkinan terjadinya senjangan anggaran. Hal ini juga berkaitan dengan Theory of Planned Behavior (TPB) yang berkaitan dengan perilaku terencana yang dilakukan oleh seseorang. Senjangan anggaran yang merupakan suatu tindakan yang dilakukan dengan terencana untuk mendapatkan kinerja yang terlihat baik maka dapat diantisipasi dengan adanya kejelasan sasaran anggaran yang jelas. Jika sasaran anggaran yang ditetapkan semakin jelas maka senjangan anggaran yang dapat terjadi akan semakin rendah. Agusti, (2013) meneliti mengenai pengaruh kejelasan sasaran anggaran terhadap senjangan anggaran pada apparat pemerintahan Kota Pekanbaru dan memperoleh hasil bahwa kejelasan sasaran anggaran berpengaruh negatif terhadap senjangan anggaran. Hasil dari penelitian ini didukung oleh penelitian yang dilakukan oleh Suhartono \& Solichin, (2006) pada instansi pemerintahan daerah di wilayah Daerah Istimewa Yogyakarta yang menunjukkan bahwa kejelasan sasaran anggaran berpengaruh negatif signifikan terhadap senjangan anggaran. Berdasarkan penelitian-penelitian terdahulu, maka hipotesis dari penelitian ini sebagai berikut.

$\mathrm{H}_{2}$ : Kejelasan sasaran anggaran berpengaruh negatif terhadap senjangan anggaran.

Kohesivitas kelompok dapat mempengaruhi kinerja individu dalam kelompok yang berdampak terhadap hasil pekerjaannya dalam kelompok. Berdasarkan teori agensi, kohesivitas kelompok diduga dapat menyebabkan senjangan anggaran karena hubungan yang kuat ketika menjalankan tugasnya dalam suatu kelompok untuk menyusun anggaran yang menyebabkan untuk lebih mementingkan tujuan kelompok daripada tujuan organisasi atau perusahaannya. Selain itu juga, jika setiap anggota dalam kelompok memiliki 
komitmen yang tinggi dalam mempertahankan kelompoknya, maka anggota kelompok juga akan lebih mementingkan tujuan kelompok daripada tujuan organisasi atau perusahaan terkait dalam hal menyusun anggaran serta pelaksanaan anggaran. Maka hipotesis dari penelitian sebagai berikut.

$\mathrm{H}_{3}$ : Kohesivitas Kelompok berpengaruh positif terhadap senjangan anggaran.

\section{METODE PENELITIAN}

Lokasi penelitian ini adalah di Rumah Sakit Daerah Mangusada Kabupaten Badung. Alasan peneliti memilih Rumah Sakit Daerah Mangusada Kabupaten Badung karena Kabupaten Badung memiliki APBD dengan skala ekonomi terbesar di Bali dengan pendapatan selama tahun 2018 mencapai $R p$ 6,5 triliun dan belanja tercatat sebesar Rp 7,2 triliun. Selain itu proses penyusunan anggaran pada rumah sakit mempunyai kompleksitas yang cukup rumit, serta rumah sakit bertujuan untuk memaksimalkan pelayanan dan meminimalkan biaya sehingga tingkat persaingan rumah sakit yang ada semakin kompetitif sehingga diperlukan perencanaan anggaran yang efektif dan pengawasan biaya agar rumah sakit dapat terus meningkatkan pelayanan semaksimal mungkin dengan meminimalkan biaya. Obyek dari penelitian ini adalah partisipasi anggaran, kejelasan sasaran anggaran, kohesivitas kelompok dan senjangan anggaran.

Populasi dalam penelitian ini adalah seluruh pejabat atau pegawai di Rumah Sakit Daerah Mangusada Kabupaten Badung. Pemilihan sampel ini menggunakan metode purposive sampling dengan tujuan mendapatkan sampel yang representatif yang sesuai dengan kriteria yang telah ditentukan. Purposive sampling merupakan teknik penentuan sampel dengan pertimbangan tertentu sesuai dengan tujuan penelitian. Sampel dalam penelitian ini dipilih secara tidak acak disesuaikan dengan karakteristik relevan dengan tujuan penelitian yang mudah diperoleh yaitu direktur, kepala bagian, kepala bidang, kepala seksi, dan beberapa staf pegawai yang terlibat dalam proses penyusunan anggaran di Rumah Sakit Daerah Mangusada Kabupaten Badung. Adapun kriteria yang digunakan dalam pemilihan sampel yaitu pegawai yang mempunyai jabatan struktural dalam Rumah Sakit Daerah Mangusada Kabupaten Badung serta terlibat dalam proses penyusunan anggaran.

Dalam analisis regresi linier berganda terlebih dahulu melakukan uji asumsi klasik yang terdiri dari uji normalitas, uji multikolimearitas dan uji heteroskedastisitas untuk mengetahui hubungan antara variabel bebas dan variabel terikat. Jika variabel sudah terbebas dari gejala asumsi klasik maka selanjutnya diuji dengan analisis regresi linier berganda untuk menghitung besarnya pengaruh variabel $X$ dan $Y$, yang diukur dengan menggunakan koefisien regresi, metode ini menghubungkan variabel dependen dan variabel independen. Untuk membuktikan kebenaran adanya pengaruh variabel dependen dan variabel independen digunakan analisis regresi dimana variabel bebas $(X)$ adalah Partisipasi Anggaran, Kejelasan Sasaran Anggaran dan Kohesivitas Kelompok, sedangkan variabel terikat $(Y)$ adalah Senjangan Anggaran. Pengujian yang dilakukan dalam penelitian ini yaitu Uji validitas, uji reliabilitas, uji statistik deskriptif, uji asumsi klasik, uji regresi linier berganda, uji koefisien determinasi, uji $f$ dan uji t.

$Y=\alpha+\beta_{1} X_{1}+\beta_{2} X_{2}+\beta_{3} X_{3}+\varepsilon$ 


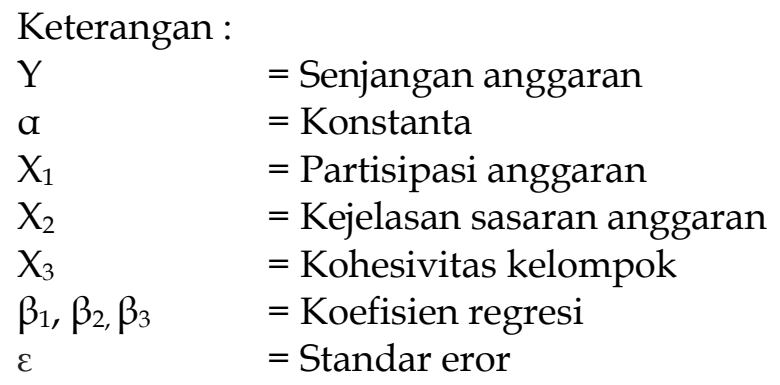

\section{HASIL DAN PEMBAHASAN}

Statistik deskriptif dalam penelitian ini memberikan informasi mengenai kecenderungan responden yang mengisi kuesioner pada indikator masing-masing variabel yang terdapat pada pertanyaan dalam kuesioner penelitian. Pengukuran kecenderungan responden pada indikator masing-masing variabel diukur menggunakan nilai rata-rata (mean). Hasil statistik deskriptif dapat dilihat pada Tabel 1 Sebagai berikut:

\section{Tabel 1. Hasil Uji Statistik Deskriptif}

\begin{tabular}{|c|c|c|c|c|c|}
\hline Variabel & $\mathrm{N}$ & Minimum & Maximum & Mean & $\begin{array}{l}\text { Std. } \\
\text { Deviation }\end{array}$ \\
\hline Senjangan Anggaran (Y) & 36 & 12.00 & 24.00 & 16.8611 & 2.65279 \\
\hline Partisipasi Anggaran (X1) & 36 & 6.00 & 20.00 & 13.7500 & 3.21936 \\
\hline $\begin{array}{ll}\text { Kejelasan } & \text { Sasaran } \\
\text { Anggaran (X2) } & \end{array}$ & 36 & 16.00 & 28.00 & 22.2778 & 2.74238 \\
\hline Kohesivitas Kelompok (X3) & 36 & 42.00 & 60.00 & 49.9722 & 5.37447 \\
\hline
\end{tabular}

Sumber: Data Penelitian, 2019

Variabel senjangan anggaran $(\mathrm{Y})$ memiliki nilai minimum sebesar 12,00 dan nilai maksimum sebesar 24,00. Nilai rata-rata untuk variabel senjangan anggaran adalah sebesar 16,8611 yang berarti rata-rata senjangan anggaran pada sampel amatan dalam penelitian ini bernilai 16,8611. Standar deviasi sebesar 2,65279 yang memiliki makna bahwa terjadi penyimpangan data pada nilai rataratanya adalah sebesar 2,65279.

Variabel partisipasi anggaran (X1) memiliki nilai minimum sebesar 6,00 dan nilai maksimum sebesar 20,00. Nilai rata-rata untuk variabel senjangan anggaran adalah sebesar 13,7500 yang berarti rata-rata senjangan anggaran pada sampel amatan dalam penelitian ini bernilai 13,7500. Standar deviasi sebesar 3,21936 yang memiliki makna bahwa terjadi penyimpangan data pada nilai rata-ratanya adalah sebesar 3,21936.

Variabel kejelasan sasaran anggaran (X2) memiliki nilai minimum sebesar 16,00 dan nilai maksimum sebesar 28,00. Nilai rata-rata untuk variabel senjangan anggaran adalah sebesar 22,2778 yang berarti rata-rata senjangan anggaran pada sampel amatan dalam penelitian ini bernilai 22,2778. Standar deviasi sebesar 2,74238 yang memiliki makna bahwa terjadi penyimpangan data pada nilai rataratanya adalah sebesar 2,74238.

Variabel kohesivitas kelompok (X3) memiliki nilai minimum sebesar 42,00 dan nilai maksimum sebesar 60,00. Nilai rata-rata untuk variabel senjangan anggaran adalah sebesar 49,9722 yang berarti rata-rata senjangan anggaran pada sampel amatan dalam penelitian ini bernilai 49,9722. Standar deviasi sebesar 
5,37447 yang memiliki makna bahwa terjadi penyimpangan data pada nilai rataratanya adalah sebesar 5,37447.

Sebelum dianalisis dengan teknik regresi, maka model persamaan regresi harus melalui uji asumsi klasik. Model regresi yang baik adalah model regresi yang di dalamnya tidak terdapat masalah data yang distribusinya normal, masalah multikolinearitas, dan masalah heteroskedastisitas. Adapun pengujian asumsi klasik yang dilakukan yaitu: uji normalitas, uji multikolinearitas, dan uji heteroskedastisitas. Adapun hasil uji asumsi klasik penelitian ini akan dipaparkan pada penjelasan berikut:

1) Uji Normalitas Data

Uji normalitas ini bertujuan untuk mengetahui apakah residual dari model regresi yang dibuat berdistribusi normal atau tidak. Dalam penelitian ini uji normalitas dilakukan dengan menguji normalitas residual dengan menggunakan uji Kolmogorov-Smirnov. Jika probabilitas signifikansi nilai residual lebih besar dari 0,05 maka data tersebut dikatakan berdistribusi normal. Demikian pula sebaliknya, jika probabilitas signifikansi residual lebih rendah dari 0,05 maka data tersebut dikatakan tidak berdistribusi normal.

Tabel 2. Hasil Uji Normalitas

\begin{tabular}{lll}
\hline $\mathrm{N}$ & & 36 \\
\hline Normal Parameters & & \\
& Mean & .0000000 \\
Most Extreme Differences & Std. Deviation & 1.92428165 \\
& Absolute & .078 \\
& Positive & .078 \\
Kolmogorov-Smirnov Z & Negative & -.076 \\
Asymp. Sig. (2-tailed) & & .470 \\
\hline
\end{tabular}

Sumber: Data Penelitian, 2019

Berdasarkan hasil analisis pada Tabel 2, didapat nilai signifikansi sebesar 0,980 yang lebih besar dari 0,05. Oleh karena nilai signifikansi uji KolmogorovSmirnov lebih dari 0,05 maka dapat disimpulkan bahwa model persamaan regresi tersebut berdistribusi normal.

Uji multikolinearitas bertujuan untuk menguji apakah dalam satu model regresi ditemukan adanya korelasi antar variabel bebas. Model regresi yang baik adalah tidak terjadi korelasi diantara variabel bebas. Untuk mendeteksi ada atau tidaknya korelasi antar variabel bebas dapat dilihat dari nilai tolerance dan nilai variance inflation factor (VIF). Jika nilai tolerance lebih dari $10 \%$ atau VIF Kurang dari 10, maka dapat dikatakan model telah bebas dari multikolinearitas. Adapun hasil uji multikolinieritas dapat dilihat pada Tabel berikut:

Tabel 3. Hasil Uji Multikoleniaritas

\begin{tabular}{llll}
\hline Variabel & Tolerance & VIF & Keterangan \\
\hline Partisipasi anggaran $\left(\mathrm{X}_{1}\right)$ & 0,925 & 1,081 & Bebas multikol \\
Kejelasan sasaran anggaran $\left(\mathrm{X}_{2}\right)$ & 0,708 & 1,412 & Bebas multikol \\
Kohesivitas kelompok $\left(\mathrm{X}_{3}\right)$ & 0,689 & 1,452 & Bebas multikol \\
\hline
\end{tabular}

Sumber: Data Penelitian, 2019

Berdasarkan Tabel 3, dapat dilihat bahwa nilai tolerance dan VIF dari seluruh variable tersebut menunjukkan bahwa nilai tolerance untuk setiap variabel lebih besar dari $10 \%$ dan nilai VIF lebih kecil dari 10 yang berarti model persamaan regresi bebas dari multikolinearitas. 
Uji heteroskedastisitas ini bertujuan untuk mengetahui apakah dalam model regresi terjadi ketidaksamaan varians dari residual satu pengamatan ke pengamatan lain yang dilakukan dengan uji Glejser. Model regresi yang baik adalah yang tidak mengandung gejala heteroskedastisitas atau mempunyai varians yang homogen. Jika variabel bebas yang diteliti tidak mempunyai pengaruh signifikan atau nilai signifikansinya lebih dari 0,05 terhadap nilai absolute residual, berarti model regresi tidak mengandung gejala heteroskedastisitas. Hasil pengujian heteroskedastisitas disajikan pada Tabel 4, berikut.

Tabel 4. Hasil Uji Heteroskedastisitas

\begin{tabular}{|c|c|c|c|c|c|c|}
\hline \multirow{2}{*}{\multicolumn{2}{|c|}{ Model }} & \multicolumn{2}{|c|}{$\begin{array}{l}\text { Unstandardized } \\
\text { Coefficients }\end{array}$} & \multirow{2}{*}{$\begin{array}{l}\text { Standardized } \\
\text { Coefficients } \\
\text { Beta }\end{array}$} & \multirow[b]{2}{*}{$\mathrm{t}$} & \multirow[b]{2}{*}{ Sig. } \\
\hline & & $\mathrm{B}$ & Std. Error & & & \\
\hline \multirow[t]{4}{*}{1} & (Constant) & 3.421 & 1.779 & & 1.923 & .063 \\
\hline & Partisipasi Anggaran & -.086 & .054 & -.281 & -1.608 & .118 \\
\hline & $\begin{array}{l}\text { Kejelasan } \\
\text { Anggaran }\end{array}$ & -.089 & .072 & -.247 & -1.240 & .224 \\
\hline & Kohesivitas Kelompok & .028 & .037 & .150 & .741 & .464 \\
\hline
\end{tabular}

Sumber: Data Penelitian, 2019

Pada Tabel 4, dapat dilihat bahwa nilai Signifikansi dari variabel partisipasi anggaran sebesar 0,118, kejelasan sasaran anggaran sebesar 0,224 dan kohesivitas kelompok 0,464. Nilai tersebut lebih besar dari 0,05 yang berarti tidak terdapat pengaruh antara variabel bebas terhadap absolute residual. Dengan demikian, model yang dibuat tidak mengandung gejala heteroskedastisitas.

Berdasarkan uraian pada Tabel 2, Tabel 3, dan Tabel 4, menunjukkan bahwa semua uji asumsi klasik sudah terpenuhi sehingga hasil analisis regresi layak untuk dibahas lebih lanjut.

Setelah semua asumsi klasik terpenuhi, maka selanjutnya memaparkan hasil analisis regresi linier berganda. Perhitungan koefisien regresi linier berganda dilakukan dengan analisis regresi melalui software SPSS 18.0 for Windows, diperoleh hasil yang ditunjukan pada Tabel 5

Tabel 5. Hasil Analisis Regresi Linier Berganda

\begin{tabular}{lllllll}
\hline Model & \multicolumn{2}{l}{$\begin{array}{l}\text { Unstandardized } \\
\text { Coefficients }\end{array}$} & \multicolumn{2}{l}{$\begin{array}{l}\text { Standardized } \\
\text { Coefficients }\end{array}$} & \\
\cline { 2 - 5 } & $\mathrm{B}$ & Std. Error & Beta & $\mathrm{t}$ & Sig. \\
\hline 1 & (Constant) & 13.175 & 3.647 & & 3.612 & .001 \\
& Partisipasi Anggaran & .345 & .110 & .419 & 3.141 & .004 \\
& Kejelasan Sasaran Anggaran & -.484 & .147 & -.500 & -3.284 & .002 \\
\multicolumn{2}{l}{ Kohesivitas Kelompok } & .195 & .076 & .394 & 2.551 & .016 \\
\hline
\end{tabular}

Sumber: Data Penelitian, 2019

Berdasarkan hasil analisis regresi linier berganda seperti yang disajikan pada Tabel 5, maka dapat dibuat persamaan regresi sebagai berikut.

$$
\mathrm{Y}=13,175+0,345 \mathrm{X}_{1}-0,484 \mathrm{X}_{2}+0,195 \mathrm{X}_{3}
$$

Nilai koefisien regresi masing-masing variabel bebas memiliki nilai signifikansi uji $\mathrm{t}$ kurang dari 0,05 . Hal ini menunjukkan bahwa semua variabel bebas memiliki pengaruh yang signifikan terhadap variabel terikat.

Koefisien determinasi $\left(\mathrm{R}^{2}\right)$ digunakan untuk mengetahui dan mengukur kemampuan model dalam menerangkan variasi variabel independen. Peneliti 
menggunakan nilai adjusted $\mathrm{R}^{2}$ pada saat mengevaluasi yang mana model regresi terbaik, karena tidak seperti $\mathrm{R}^{2}$, nilai adjusted $\mathrm{R}^{2}$ dapat naik atau turun apabila satu variabel independen ditambahkan ke dalam model. Hasil uji koefisien determinasi dapat dilihat pada Tabel 6 berikut.

Tabel 6. Hasil Uji Koefisien Determinasi $\left(\mathbf{R}^{2}\right)$

\begin{tabular}{llllllr}
\hline Model & & & & Std. Error of the \\
& $\mathrm{R}$ & $\mathrm{R}$ Square & Adjusted $\mathrm{R}$ Square & $\begin{array}{l}\text { Estimate } \\
\text { Estimen }\end{array}$ \\
\hline 1 & $.688^{\mathrm{a}}$ & .474 & .424 & 2.01246 & \\
\hline
\end{tabular}

Sumber: Data Penelitian, 2019

Hasil uji pada Tabel 6, memberikan hasil dimana diperoleh besarnya adjusted $\mathrm{R}^{2}$ (koefisien determinasi yang telah disesuaikan) adalah sebesar 0,424. Ini berarti variasi senjangan anggaran dapat dipengaruhi secara signifikan oleh variabel partisipasi anggaran, kejelasan sasaran anggaran dan kohesivitas kelompok sebesar 42,4 persen, sedangkan sisanya sebesar 57,6 persen dijelaskan oleh faktor-faktor lain yang tidak dijelaskan dalam model penelitian.

Uji simultan bertujuan untuk mengetahui apakah semua variabel bebas yang diidentifikasi (partisipasi anggaran, kejelasan sasaran anggaran, dan kohesivitas kelompok) tepat digunakan memprediksi senjangan anggaran secara bersama-sama. Uji ini sering juga disebut dengan uji F. Hasil uji $F$ dalam penelitian ini dapat dilihat pada Tabel 7 , berikut.

\section{Tabel 7. Hasil Uji F}

\begin{tabular}{lllllll}
\hline Model & & Sum of Squares & $d f$ & Mean Square & F & Sig. \\
\hline 1 & Regression & 116.705 & 3 & 38.902 & 9.605 & $.000^{\mathrm{a}}$ \\
& Residual & 129.600 & 32 & 4.050 & & \\
& Total & 246.306 & 35 & & & \\
\end{tabular}

Sumber: Data Penelitian, 2019

Hasil uji F (Ftest) menunjukkan bahwa nilai signifikansi P value 0,000 yang lebih kecil dari $a=0,05$, ini berarti model yang digunakan pada penelitian ini adalah layak. Hasil ini memberikan makna bahwa seluruh variabel independen mampu memprediksi atau menjelaskan fenomena senjangan anggaran. Dengan kata lain ada pengaruh secara simultan dari variabel partisipasi anggaran, kejelasan sasaran anggaran, dan kohesivitas kelompok terhadap senjangan anggaran. Hal ini berarti model dapat digunakan untuk analisa lebih lanjut atau dengan kata lain model dapat digunakan untuk memproyeksikan karena hasil goodness of fitnya baik dengan nilai signifikansi P value 0,000

Pengaruh variabel partisipasi anggaran, kejelasan sasaran anggaran dan kohesivitas kelompok terhadap senjangan anggaran yang diuji dengan menggunakan Uji t. Kriteria pengujian untuk menjelaskan interpretasi pengaruh antar masing-masing variabel yakni apabila nilai signifikansi $<0,05$ maka $\mathrm{H}_{0}$ ditolak dan $\mathrm{H}_{1}$ diterima. Sebaliknya, jika nilai signifikansi $>0,05$ maka $\mathrm{H}_{0}$ diterima dan $\mathrm{H}_{1}$ ditolak.

Berdasarkan hasil analisis pengaruh partisipasi anggaran terhadap senjangan anggaran diperoleh nilai signifikasi sebesar 0,004 dengan nilai koefisien regresi positif sebesar 0,345. Nilai Signifikansi 0,004 < 0,05 mengindikasikan bahwa $\mathrm{H}_{0}$ ditolak dan $\mathrm{H}_{1}$ diterima. Hasil ini mempunyai arti bahwa Partisipasi anggaran berpengaruh positif dan signifikan terhadap Senjangan anggaran. 
Berdasarkan hasil analisis pengaruh kejelasan sasaran anggaran terhadap senjangan anggaran diperoleh nilai signifikansi sebesar 0,002 dengan nilai koefisien regresi negatif sebesar -0,484. Nilai Signifikansi 0,002 $<0,05$ mengindikasikan bahwa $\mathrm{H}_{0}$ ditolak dan $\mathrm{H}_{2}$ diterima. Hasil ini mempunyai arti bahwa Kejelasan sasaran anggaran berpengaruh negatif dan signifikan terhadap Senjangan anggaran.

Berdasarkan hasil analisis pengaruh kohesivitas kelompok terhadap senjangan anggaran diperoleh nilai signifikansi sebesar 0,016 dengan nilai koefisien regresi positif sebesar 0,195. Nilai Signifikansi 0,016 $<0,05$ mengindikasikan bahwa $\mathrm{H}_{0}$ ditolak dan $\mathrm{H}_{3}$ diterima. Hasil ini mempunyai arti bahwa Kohesivitas kelompok berpengaruh positif dan signifikan terhadap Senjangan anggaran.

\section{SIMPULAN}

Penelitian ini menguji pengaruh partisipasi anggaran, kejelasan sasaran anggaran, dan kohesivitas kelompok terhadap senjangan anggaran. Lokasi penelitian ini dilakukan di RSD Mangusada Kabupaten Badung. Berdasarkan hasil dan pembahasan, Partisipasi anggaran berpengaruh positif dan signifikan terhadap senjangan anggaran di RSD Mangusada Kabupaten Badung. Hal ini berarti semakin tinggi partisipasi yang dilakukan dalam menyusun anggaran maka semakin tinggi juga tingkat senjangan anggaran yang terjadi. Kejelasan sasaran anggaran berpengaruh negatif dan signifikan terhadap senjangan anggaran di RSD Mangusada Kabupaten Badung. Hal ini berarti semakin jelas sasaran anggaran yang ditetapkan maka semakin rendah tingkat senjangan anggaran yang dapat terjadi. Kohesivitas kelompok berpengaruh positif dan signifikan terhadap senjangan anggaran di RSD Mangusada Kabupaten Badung. Hal ini berarti semakin tinggi kohesivitas kelompok yang dilakukan dalam menyusun anggaran maka semakin tinggi juga tingkat senjangan anggaran yang dapat terjadi. Berdasarkan simpulan penelitian, maka saran yang dapat disampaikan bagi Rumah Sakit Daerah Mangusada Kabupaten Badung yaitu dalam proses partisipasi anggaran diharapkan untuk meningkatkan kontrol dan pengawasan dalam proses partisipasi anggaran agar sewaktu anggaran disusun tidak terjadinya senjangan anggaran. Dalam proses penyusunan dan penetapan anggaran dibutuhkan adanya kejelasan sasaran anggaran sehingga diharapkan untuk menetapkan sasaran anggaran yang jelas berdasarkan tingkat kepentingan serta tingkat kesulitan pencapaian target anggaran sehingga anggaran dapat dipahami dengan jelas dan spesifik. Kohesivitas kelompok merupakan hal yang penting, namun diharapkan untuk lebih meningkatkan komitmen yang kuat dalam kelompok terkait penyusunan serta pelaksanaan anggaran.

\section{REFERENSI}

Agusti, R. (2013). Pengaruh Kejelasan Sasaran Anggaran Terhadap Senjangan Anggaran Dengan Dimoderasi oleh Variabel Komitmen Organisasi dan Informasi Asimetri. Jurnal Ekonomi, 19(4), 1-10.

Arthaswadaya, A. (2015). Pengaruh Asimetri Informasi terhadap Budgetary Slack dengan Self Esteem sebagai Variabel Pemoderasi : Studi Eksperimen dalam Konteks Penganggaran Partisipatif. Jurnal Akuntansi Universitas Yogyakarta, 1- 
163.

Biantara, A., \& Dwija Putri, I. (2014). Pengaruh Kejelasan Sasaran Anggaran, Etika, Dan Kepercayaan Diri Pada Senjangan Anggaran. E-Jurnal Akuntansi, 9(2), 385-391.

Dianthi, I. A. G. P., \& Wirakusuma, M. G. (2017). Pengaruh Partisipasi Penganggaran, Asimetri Informasi, Budaya Organisasi Dan Komitmen Organisasi Pada Senjangan Anggaran. E-Jurnal Akuntansi Universitas Udayana ISSN : 2302-8556, 18(2), 874-901.

Erina, N. P. D., \& Suartana, W. (2016). Pengaruh Partisipasi Penganggaran, Penekanan Anggaran, Kapasitas Individu, dan Kejelasan Sasaran Anggaran pada Senjangan Anggaran. E-Jurnal Akuntansi Unud, 15(9), 1689-1699. https://doi.org/10.1017/CBO9781107415324.004

Falikhatun. (2007). Pengaruh Partisipasi Penganggaran Terhadap Budgetary Slack dengan Variabel Pemoderasi Ketidakpastian Lingkungan dan Kohesivitas Kelompok. Jurnal Akuntansi Dan Keuangan, 6(2), 1-15.

Lau, C. M., \& Eggleton, R. C. (2003). The Influence of Information Asymmetry and Budget Emphasis on the Relationship between Participation and Slack. Accounting and Business Research, 33(2), 91-104.

Lestari, N. K. R., \& Wisadha, I. G. S. (2015). Pengaruh Partisipasi Penganggaran pada Senjangan Anggaran dengan Group Cohesiveness sebagai Variabel Pemoderasi. 13(2), 418-428.

Pitasari, K. K. A., Sulindawati, N. L. G. E., \& Atmadja, A. T. (2014). Pengaruh Kejelasan Sasaran Anggaran dan Keadilan Prosedural terhadap Sejangan Anggaran ( Budgetary Slack ) pada SKPD berupa Dinas di Pemerintah Kabupaten Klungkung. E-Journal S1 Ak Universitas Pendidikan Ganesha, 2(1), $1-12$.

Rahman, F. A. (2009). Pengaruh Kejelasan Sasaran Anggaran terhadap Senjangan Anggaran dengan Komitmen Organisasi sebagai Pemoderasi. Jurnal Ekonomi, Manajemen Dan Akuntansi, 15(1), 1-10.

Rahmiati, E. (2013). Pengaruh Partisipasi Anggaran terhadap Senjangan Anggaran dengan Asimetri Informasi dan Komitmen Organisasi sebagai Pemoderasi. Universitas Negeri Padang, (434), 1-20.

Robbins, S. P., \& Judge, T. A. (2006). Perilaku Organisasi. Edisi Bahasa Indonesia. Jakarta: PT. Indeks Kelompok Gramedia.

Suhartono, E., \& Solichin, M. (2006). Pengaruh Kejelasan Sasaran Anggaran Terhadap Senjangan Anggaran Instansi Pemerintah Daerah Dengan Komitmen Organisasi Sebagai Pemoderasi. Jurnal Akuntansi Dan Keuangan Sektor Publik, 8(1), 1-20.

Widanaputra, A. A., \& Mimba, N. P. S. H. (2014). The Influence of Participative Budgeting on Budgetary Slack in Composing Local Governments' Budget in Bali Province. Procedia - Social and Behavioral Sciences, 164, 391-396. https://doi.org/10.1016/j.sbspro.2014.11.093 